\title{
The Relationship Between Myocardial Performance Index and Renal Resistive Index in Resistant Hypertension
}

\section{Dirençli Hipertansiyonda Miyokard Performans İndeksi ile Renal Rezistif İndeks Arasındaki İlişki}

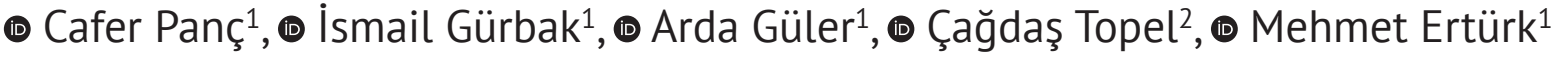 \\ ${ }^{1}$ University of Health Sciences Turkey, Mehmet Akif Ersoy Thoracic and Cardiovascular Surgery Training and Research Hospital, Clinic of Cardiology, Istanbul, Turkey \\ ${ }^{2}$ University of Health Sciences Turkey, Mehmet Akif Ersoy Thoracic and Cardiovascular Surgery Training and Research Hospital, Clinic of Radiology, Istanbul, Turkey
}

Background: Renal resistive index (RRI), an index measured in renal arteries, is related to cardiac structural changes. Myocardial performance index (MPI), a valuable method to show subclinical myocardial dysfunction, contributes to risk assessment due to detecting the early stages of diastolic and systolic dysfunctions. We aimed to examine the relationship between RRI and MPI in resistant hypertension (RHT).

Materials and Methods: One hundred and twenty-six patients who were admitted to our outpatient clinic were enrolled in this single-center, cross-sectional prospective study. All patients underwent echocardiography and renal Doppler ultrasound. Two groups were created according to the presence of subclinical left ventricle (LV) dysfunction: patients with lower $\mathrm{MPI} g r o u p(\mathrm{MPI}<0.5, \mathrm{n}=50)$ and patients with higher MPI group (MPI $\geqslant 0.5, \mathrm{n}=76$ ).

Results: Higher MPI group was associated with higher LV end-diastolic diameter, LV mass index, left atrium diameter, LV end-systolic diameter, posterior wall diameter, E velocity, interventricular septum diameter, and RRI. In multivariable logistic regression analysis, age [odds ratio (OR): 1.070,95\% confidence interval (Cl): 1.016-1.126, $\mathrm{p}=0.010$ ], left atrium diameter (OR: 1.111,95\% Cl: 1.027-1.202, $p=0.008$ ) and RRI (OR: 6.404, 95\% Cl: 2.767-19.899, $p<0.025)$ were associated with subclinical LV dysfunction. RRI showed a good positive correlation with MPI $(r=0.527, p<0.001)$.

Conclusion: Our study suggests that increased RRI is associated with subclinical LV dysfunction assessed by increased MPI in patients with RHT.

Keywords: Resistant hypertension, myocardial performance index, renal resistive index

Amaç: Doppler ultrason ile değerlendirilen renal rezistif indeks (RRI), hipertansif hastalarda yapısal kardiyak değişiklikler ile ilişkilidir. Doku Doppler ekokardiyografi ile elde edilen miyokardiyal performans indeksi (MPI) sistolik ve diyastolik fonksiyonları aynı anda gösterir. Çalışmanın amacı dirençli hipertansiyonu (RHT) olan hastalarda RRI ve MPI arasındaki ilişkiyi araştırmaktır.

Gereç ve Yöntemler: Bu prospektif çalışma, dirençli hipertansiyonu olan 126 poliklinik hastasını (\%59,5 kadın, ortalama yaş 58ะ9 yıl) kapsamaktadır. Tüm hastalara ekokardiyografi ve renal Doppler ultrason yapıldı. Hastalar subklinik sol ventrikül (SV) disfonksiyonunun varlığına göre iki gruba ayrıldı: Düşük MPI grubu $(\mathrm{MPI}<0,5, \mathrm{n}=50)$ ve yüksek MPI grubu (MPI 00,5, n=76).

Bulgular: Yüksek MPI grubu, daha yüksek SV diyastolik çapı, SV sistolik çapı, interventriküler septum çapı, arka duvar çapı, SV kitle indeksi, sol atriyum çapı, E hızı ve RRI ile ilişkili olarak bulundu. Çok değişkenli lojistik regresyon analizinde, yaş [olasılık oranı (OR): 1.070, \%95 güven aralığı (CI): 1.016-1.126, p=0,010], sol atrium çapı (OR: 1.111, \%95 Cl: 1.027-1.202, p=0,008) ve RRI (OR: 6.404, \%95 Cl: 2.767-19.899, p<0,025) subklinik SV disfonksiyonu ile ilişkili olarak bulundu. Korelasyon analizinde, RRI, MPI ile iyi bir pozitif korelasyon gösterdi $(r=0,527, p<0,001)$.

Sonuç: Çalışmamız, artmış RRI'nin RHT’li hastalarda artmış MPI ile değerlendirilen subklinik LV disfonksiyonu ile ilişkili olduğunu düşündürmektedir.

Anahtar Kelimeler: Dirençli hipertansiyon, miyokardiyal performans indeksi, renal rezistif indeks

\footnotetext{
Address for Correspondence: Cafer Panç, University of Health Sciences Turkey, Mehmet Akif Ersoy Thoracic and Cardiovascular Surgery Training and Research Hospital, Clinic of Cardiology, İstanbul, Turkey

Phone: +90 5057184086 E-mail: caferpanc@gmail.com ORCID ID: orcid.org/0000-0003-3692-1170 Received: 22.03.2021 Accepted: 18.06 .2021 


\section{Introduction}

Resistant hypertension (RHT) is the inability to keep blood pressure under control despite using three or more drugs (one of which is a diuretic) at the maximum tolerable dose (1). Observational studies show that the prevalence of RHT is around $10-20 \%$ in the hypertensive population $(2,3)$. In RHT, constant high blood pressure values increase cardiovascular risk considerably. In extensive cross-sectional studies, RHT was strongly associated with more cardiovascular events than the other hypertensive patients $(4,5)$. Although many factors cause RHT, renal diseases are among the most common reasons.

Renal resistive index (RRI) is an index measured in renal arteries and particularly useful in demonstrating the microvascular and macrovascular interaction between the arterial system and the kidney. High resistive values ( $>0.7)$ are associated with more adverse cardiovascular events and renal failure progression (6). It reflects central arterial hemodynamics and left ventricle systolic and diastolic function $(7,8)$. Increased arterial stiffness in RHT leads to increased renal arterial circulation pressure and renal vascular resistance (9). Pulse wave velocity (PWV) was positively correlated with RRI, and PWV was an independent predictor of RRI in a cross-sectional study in hypertensive patients (10). Moreover, arterial stiffness was detected as a cause of subclinical myocardial dysfunction in another study (11). Myocardial performance index (MPI), a valuable method to show subclinical myocardial dysfunction, makes a significant contribution to risk assessment due to detecting the early stages of diastolic and systolic dysfunctions (12).

The relationship between the MPI and RRI is still unknown in RHT patients. We aimed to examine the relationship between RRI and MPI in RHT.

\section{Material and Methods}

One hundred and twenty-six patients who were admitted to our outpatient clinic were enrolled in this single-center, cross-sectional prospective study. We collected patients' medical history, prescribed drugs, and active smoking status in the initial examination. Echocardiography and renal Doppler ultrasound were performed within one week of the initial examination.

We excluded patients with chronic kidney disease (eGFR $<30 \mathrm{~mL} / \mathrm{min} / 1.73 \mathrm{~m}^{2}$ ), renal artery stenosis, nephrectomy, coronary disease, severe valvular disease, atrial fibrillation, pulmonary hypertension, heart failure (left ventricular EF $<55 \%$ ), acute or chronic infectious or inflammatory disease, malignancy, pregnancy, and chronic liver disease. We conducted the study in accordance with the Helsinki Declaration. We took a Mehmet Akif Ersoy Cardiovascular Surgery Training and Research Hospital local ethics committee approval for the study and written informed consent from all the participants.

Patients whose blood pressure remained above 140/90 despite using at least three antihypertensive drugs, one of which was a diuretic, or who used $>4$ antihypertensive drug classes in the last month, regardless of blood pressure, were accepted as RHT.

\section{Echocardiography}

All participants underwent echocardiography by a single experienced operator who did not know the patients' clinical status. According to the current guidelines, the examination was performed using a Philips Epiq 7C echocardiography device (13). We recorded tissue Doppler images at a speed of $100 \mathrm{~mm} / \mathrm{s}$ from the lateral mitral annulus. Isovolumetric contraction time (IVCT) was measured from the time from the end of the A' wave to the beginning of the S' wave. Isovolumetric relaxation time (IVRT) was measured from the time from the end of the S' wave and the beginning of the $E^{\prime}$ wave. Ejection time (ET) was found by subtracting IVCT and IVRT from total non-filling time (Figure 1). The MPI value was calculated with the formula below.

Myocardial performance index $=$ (isovolumetric contraction time + isovolumetric relaxation time)/ejection time (14).

We considered MPI $\geqslant 0.5$ as abnormal and defined it as subclinical LV dysfunction $(15,16,17)$.

\section{Renal Ultrasound and Doppler Examination}

All participants underwent ultrasonographic examination using Doppler sonography by a single experienced operator

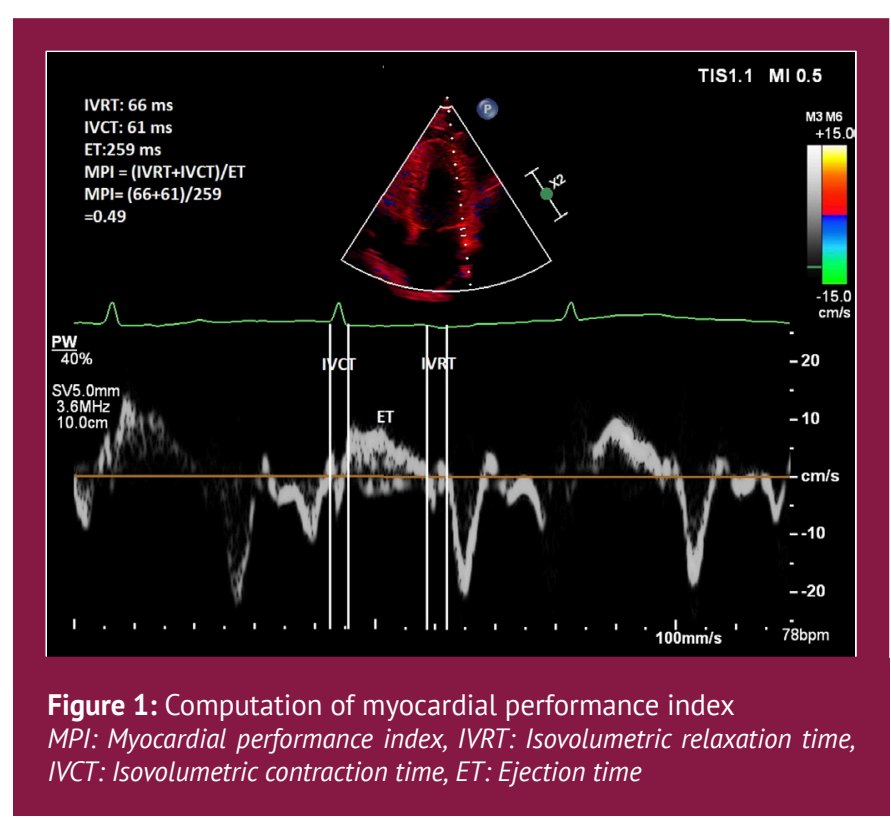


who did not know the patients' clinical data. Firstly, we assessed both kidneys for any structural pathology. After that, Doppler parameters, including peak systolic velocity (Vmax) and minimum diastolic velocity (Vmin) from interlobar arteries of both kidneys, were obtained. We calculated RRI by the following formula: Renal resistive index $=(V \max -V \min ) /$ Vmax. RRIs were calculated by taking the average of both kidneys.

\section{Statistical Analyses}

We did statistical analyses with SPSS (version 21.0 IBM, USA). We considered $\mathrm{p}<0.05$ as statistically significant. We detected the distribution of the variables with the Kolmogorov-Smirnov test. We presented quantitative variables with normal distribution as mean \pm standard deviation and non-normal distribution as median $\left(25^{\text {th }}\right.$ to $75^{\text {th }}$ percentile). We expressed categorical variables as numbers (\%). The Student's t-test for normally distributed variables and the Mann-Whitney $U$ test for non-normally distributed variables were used to compare quantitative variables. The Pearson chi-square and Fisher Exact tests were performed for categorical variables. We performed logistic regression analysis to detect the independent predictors of subclinical myocardial dysfunction. Variables with $p<0.10$ in univariable analysis were included for the multivariable logistic regression analysis with backward selection model. Correlation between MPI and RRI was assessed using the Pearson correlation analysis.

\section{Results}

We included one hundred and twenty-six outpatients with RHT. Patients were divided into two groups according to subclinical LV dysfunction: Patients with $\mathrm{MPI}<0.5$ (lower MPI group, $\mathrm{n}=50$ ) and patients with MPI 0.5 (higher MPI group, $\mathrm{n}=76)$. The higher MPI group was significantly older than the lower MPI group $(60.6 \pm 8.8$ vs. $54.9 \pm 8.2, p<0.001)$. Both groups were balanced in gender, diabetes mellitus, hyperlipidemia, smoking, body mass index, and biochemical parameters. The higher MPI group was associated with higher left ventricle end-systolic diameter (LVESd), interventricular septum diameter (IVSd), posterior wall diameter, left ventricle enddiastolic diameter (LVEDd), left ventricle mass index (LVMI), E velocity, left atrium diameter (LAd) and RRI $[0.711 \pm 0.042$ vs. $0.652 \pm 0.050, p=0.008$, (Figure 2)]. Also, the higher MPI group had a lower left ventricle ejection fraction. Baseline clinical, laboratory, and echocardiographic parameters of the patients were shown in Table 1. In multivariable logistic regression analysis, age [odds ratio (OR): 1.070, 95\% confidence interval (Cl): 1.016-1.126, $\mathrm{p}=0.010$ ], LAd (OR: $1.111,95 \% \mathrm{Cl}: 1.027-$ 1.202, $p=0.008$ ) and RRI (OR: 6.404, 95\% Cl: 2.767-19.899, $p<0.025$ ) were independent predictors of subclinical left ventricle dysfunction (Table 2). In correlation analysis, RRI showed a good positive correlation with MPI $(r=0.527$, $\mathrm{p}<0.001$ ) (Figure 3).

\section{Discussion}

Our study's main findings are as follows: 1) We found a significant correlation between RRI and MPI in patients with RHT, 2) We observed that patients with high MPI value, which is considered as LV subclinical dysfunction, were older and echocardiographic parameters associated with systolic function and diastolic dysfunction such as LV mass index, E value, and E/A were more impaired in this group, 3) According to regression analysis, we found that RRI was associated with subclinical LV dysfunction in this group of patients.

HT is a significant disease with a close relationship with cardiovascular, neurological, and renal poor outcomes. Although most hypertension cases can be treated with medications, approximately $10-20 \%$ of these patients are resistant to treatment (1). In a small study with 86 patients, it was found that RHT patients had a 2 -fold increase in cardiovascular risk than controlled HT patients (18). In another study, Sahinarslan et al. (4) showed that cardiovascular and renal damage was higher in RHT in a study including 205,750 patients. These findings are significant as the number of patients with RHT is expected to increase because of the increasing risk factors such as diabetes and obesity. End-organ damage develops faster in RHT patients and increases morbidity and mortality. In the first two years of follow-up, there were significant excess risks of these adverse outcomes, particularly MACE, cardiovascular mortality, and stroke incidence in a randomized controlled study by Cardoso and Salles (19). In a study by Gaudieri et al. (20), the coronary vascular function was shown to be more impaired in patients with $\mathrm{RHT}$, as demonstrated by myocardial perfusion reserve. Another end-organ injury that increases the risk of mortality with cardiac end-organ damage is renal function. There is a two-way relationship between renal functions and treatment resistance in patients with RHT. While the most common cause of RHT is kidney diseases, $\mathrm{RHT}$ also increases worse renal outcomes (21). Viazzi et al. (22) showed that the presence of RHT was related to impairment in renal function in hypertensive and diabetic patients with normal renal function. Considering all, both cardiac and renal involvement frequently occur in patients with RHT and simple methods showing these two end-organ damages may be important in risk classification.

MPI is an important parameter that can show systolic and diastolic functions simultaneously (23). In addition to being an early and robust predictor of left ventricular injury in the adult population, it has been associated with poor outcomes in many diseases $(24,25,26)$. It is an essential parameter for 
Table 1. Baseline features of patients

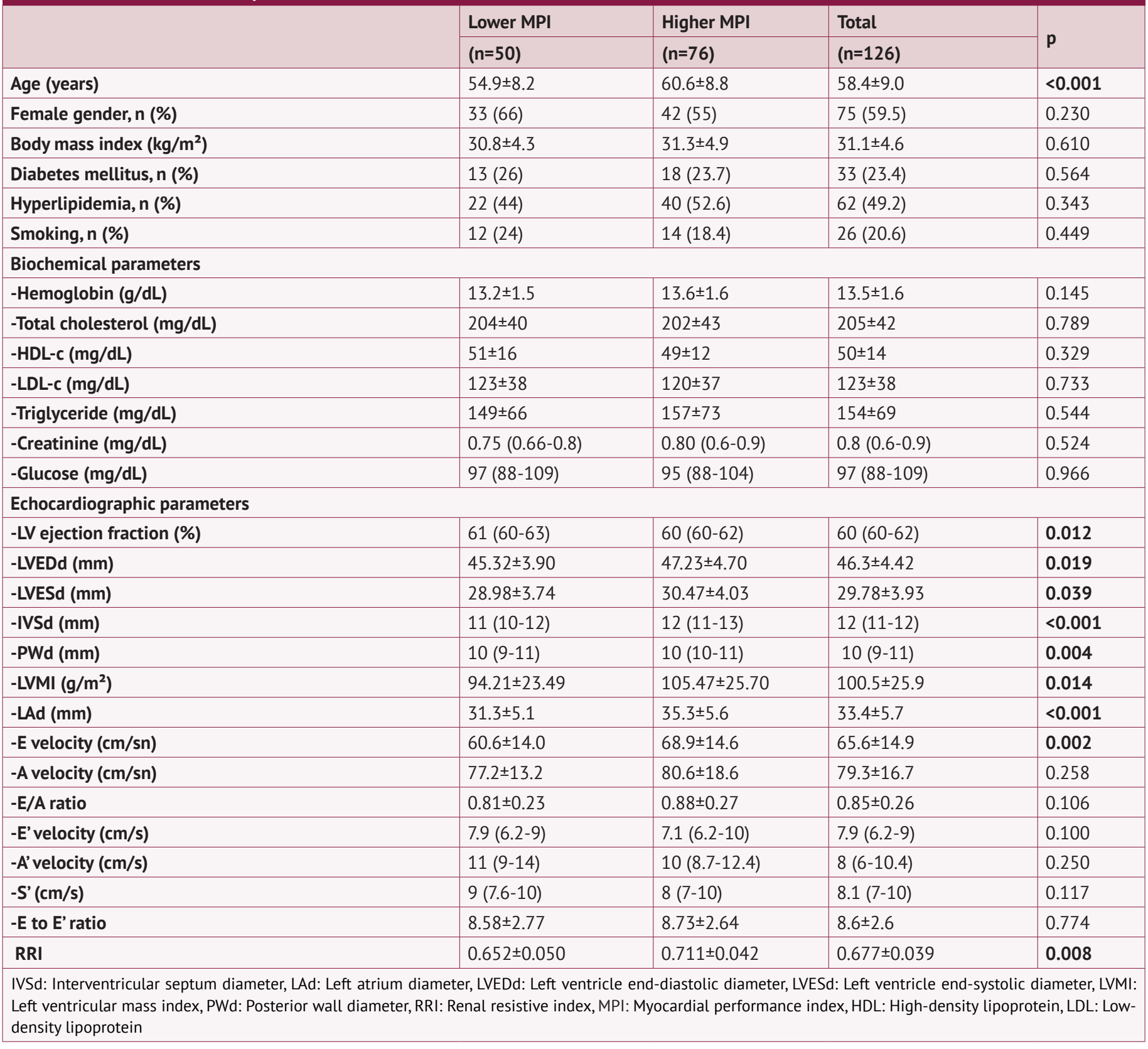

detecting left ventricular diastolic dysfunction by early stages and its association with hemodynamic changes is caused by the heart's impaired relaxation. MPI increases not only in diastolic dysfunction but also in systolic insufficiency caused by decreased pumping power (27). In our study, in parallel with these data, impaired diastolic dysfunction and systolic dysfunction were correlated with high MPI values. Ejection fraction, the most basic systolic function parameter, was lower in patients with high MPI values. In RHT patients, myocardial involvement and diastolic and systolic dysfunction are comorbid consequences that create significant end-organ damage. We hypothesize a relationship between MPI, which indicates this myocardial involvement, and renal functions, which is another crucial end-organ damage of RHT.

RRI, initially measured only in renal diseases, has gained importance as a risk factor by being evaluated in patients with cardiovascular diseases (28). Although the pathophysiological link between RRI and cardiovascular outcomes is not yet clearly understood, studies have concluded that this index is associated with renal function, renal atherosclerosis, tubulointerstitial damage, and an indicator of systemic arterial atherosclerosis (29). Tedesco et al. (30) showed that high RRI 


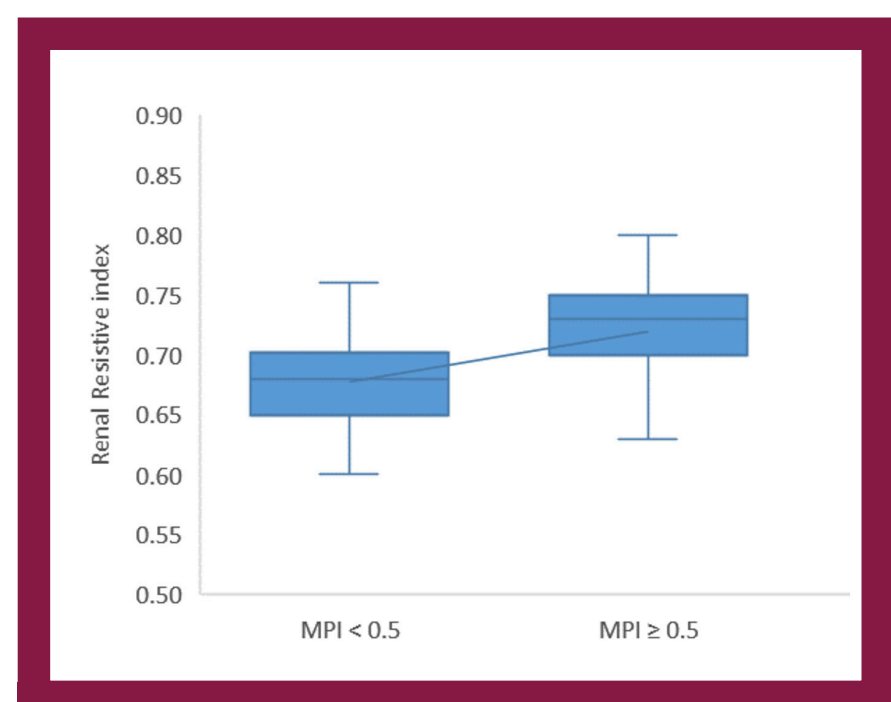

Figure 2. Comparison of renal resistive index values according to the cut-off value of MPI

MPI: Myocardial performance index levels were associated with systemic hemodynamic changes and cardiovascular parameters in hypertensive patients. In another study, high RRI values were related to carotid and coronary artery damage (29). A study conducted by Quisi et al. (31) showed a significant association between RRI and MPI in the general population. In a study, the association of renal hemodynamics with RHT was examined. They found that patients with RHT had greater levels of the renal resistive index. Also, the RRI was an independent predictor of RHT after adjusting for clinical features (32). It can be concluded that high RRI values are associated with hypertensionrelated end-organ damage in the heart. Similar to these studies' results, it has been shown that high RRI values in RHT patients correlate with MPI, which is associated with impaired myocardial function in our study.

\section{Study Limitations}

First, it was conducted in a single center, and because of that, the results cannot be generalized to the total population. Second, the sample size was small; hence, further prospective

Table 2. Univariable and multivariable logistic regression analysis with backward model selection to predict independent predictors of subclinical left ventricle dysfunction

\begin{tabular}{|c|c|c|c|c|}
\hline \multirow[t]{2}{*}{ Variables } & \multicolumn{2}{|l|}{ Univariable } & \multicolumn{2}{|c|}{$\begin{array}{l}\text { Multivariable analysis with backward } \\
\text { model selection }\end{array}$} \\
\hline & Odds ratio $(95 \% \mathrm{Cl})$ & $p$ & Odds ratio $(95 \% \mathrm{Cl})$ & $p$ \\
\hline Age & $1.081(1.033-1.131)$ & 0.005 & $1.070(1.016-1.126)$ & 0.010 \\
\hline Female gender & $1.571(0.750-2.292)$ & 0.231 & - & - \\
\hline Diabetes Mellitus & $0.883(0.387-2.014)$ & 0.768 & - & - \\
\hline Hyperlipidemia & $1.414(0.690-2.897)$ & 0.344 & - & - \\
\hline Smoking & 0.715 (0.299-1.707) & 0.450 & - & - \\
\hline Body mass index & $1.020(0.945-1.102)$ & 0.607 & - & - \\
\hline LV ejection fraction & $0.767(0.623-0.943)$ & 0.012 & - & - \\
\hline LVEDd & $1.104(1.015-1.202)$ & 0.021 & - & - \\
\hline LVESd & $1.103(1.004-1.211)$ & 0.041 & - & - \\
\hline LAd & $1.146(1.064-1.234)$ & $<0.001$ & $1.111(1.027-1.202)$ & 0.008 \\
\hline LVMI & $1.020(1.003-1.036)$ & 0.017 & - & - \\
\hline$E / A$ & $3.538(0.743-16.833)$ & 0.112 & - & - \\
\hline E'velocity & $1.220(1.007-1.477)$ & 0.042 & - & - \\
\hline A'velocity & $0.987(0.955-1.020)$ & 0.439 & - & - \\
\hline Glucose & 1.011 (0.994-1.029) & 0.200 & - & - \\
\hline Creatinine & $2.587(0.353-18.947)$ & 0.349 & - & - \\
\hline Hemoglobin & $1.189(0.943-1.483)$ & 0.148 & - & - \\
\hline Total cholesterol & $0.999(0.990-1.007)$ & 0.787 & - & - \\
\hline HDL-c & $0.988(0.964-1.012)$ & 0.326 & - & - \\
\hline LDL-c & $0.998(0.989-1.008)$ & 0.730 & - & - \\
\hline Triglyceride & $1.002(0.996-1.007)$ & 0.541 & - & - \\
\hline RRI & $6.769(1.886-24.293)$ & 0.008 & $6.404(2.767-19.899)$ & 0.025 \\
\hline
\end{tabular}




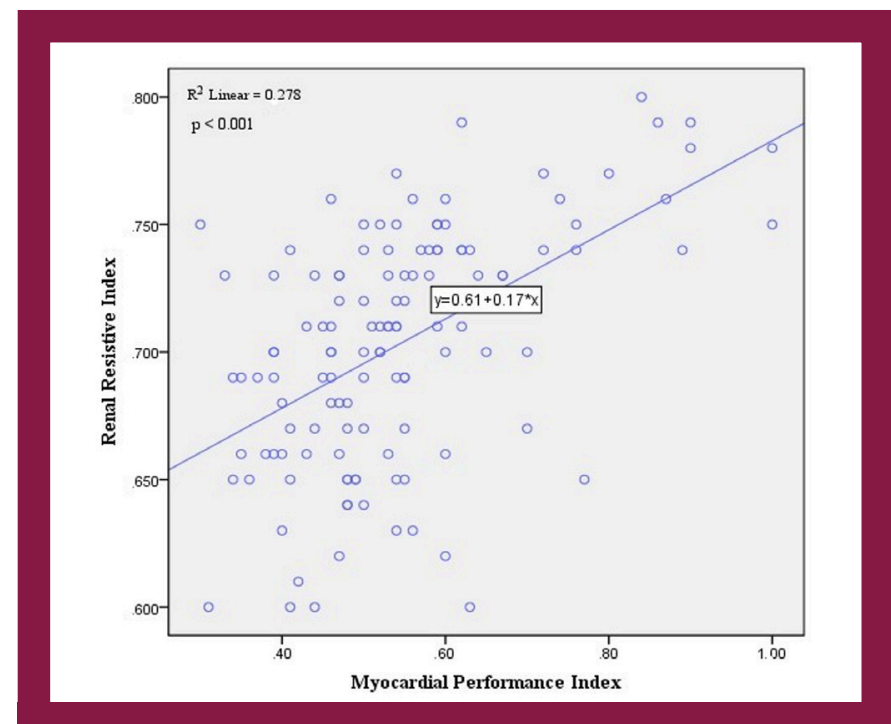

Figure 3. Association between the renal resistive index and the myocardial performance index

studies with larger cohorts may be needed to confirm the results. Finally, antihypertensive drugs can affect RRI values, and we did not evaluate the effects of the drugs.

\section{Conclusion}

Our study suggests that increased RRI is associated with subclinical LV dysfunction assessed by increased MPI in patients with RHT. In RHT, RRI assessment could play an integral role in evaluating both cardiovascular and renal damage and guiding treatment. We need future more extensive prospective studies to elucidate better the associations found in this study.

\section{Ethics}

Ethics Committee Approval: The study were approved by the Mehmet Akif Ersoy Cardiovascular Surgery Training and Research Hospital of Local Ethics Committee (Protocol number: 2020-75).

Informed Consent: Written informed consent from all the participants.

Peer-review: Internally peer-reviewed.

\section{Authorship Contributions}

Surgical and Medical Practices: C.P., Ç.T., Concept: C.P., I.G., M.E., Design: C.P., I.G., Data Collection or Processing: C.P., A.G., Analysis or Interpretation: C.P., Ç.T., Literature Search: C.P., I.G., A.G., Writing: C.P., A.G., M.E.,

Conflict of Interest: No conflict of interest was declared by the authors.

Financial Disclosure: The authors declared that this study received no financial support.

\section{References}

1. Williams B, Mancia G, Spiering W, Rosei EA, Azizi M, Burnier M, et al. 2018 ESC/ESH Guidelines for the management of arterial hypertension. Eur Heart J 2018;39:3021-104. [Crossref]

2. Noubiap JJ, Nansseu JR, Nyaga UF, Sime PS, Francis I, Bigna JJ. Global prevalence of resistant hypertension: a meta-analysis of data from 3.2 million patients. Heart. 2019;105:98-105.

3. Yakovlevitch M, Black HR. Resistant hypertension in a tertiary care clinic. Arch Intern Med.1991;151:1786-1792. [Crossref]

4. Sahinarslan A, Gazi E, Aktoz M, Ozkan C, Ulusal Okyay G, Ucar Elalmis, et al. Consensus paper on the evaluation and treatment of resistant hypertension by the Turkish Society of Cardiology. Anatol J Cardiol. 2020;24:137-152. [Crossref]

5. Sim JJ, Bhandari SK, Shi J, Reynolds K, Calhoun DA, Kalantar-Zadeh K et al. Comparative risk of renal, cardiovascular, and mortality outcomes in controlled, uncontrolled resistant, and nonresistant hypertension. Kidney Int. 2015;88:622-632.

6. Doi Y, Iwashima Y, Yoshihara F, Kamide K, Hayashi S, Kubota Y, et al. Renal resistive index and cardiovascular and renal outcomes in essential hypertension. Hypertension. 2012;60:770-777. [Crossref]

7. Kuznetsova T, Cauwenberghs N, Knez J, Knez J, Thijs L, Liu YP, et al. Doppler indexes of left ventricular systolic and diastolic flow and central pulse pressure in relation to renal resistive index. Am J Hypertens. 2015;28:535545. [Crossref]

8. Hashimoto J, Ito S. Central pulse pressure and aortic stiffness determine renal hemodynamics: pathophysiological implication for microalbuminuria in hypertension. Hypertension. 2011;58:839-846. [Crossref]

9. Safar ME, London GM, Plante GE. Arterial stiffness and kidney function. Hypertension. 2004:43:163-168. [Crossref]

10. Calabia J, Torguet P, Garcia I, Martin N, Mate G, Marin A, et al. The relationship between renal resistive index, arterial stiffness, and atherosclerotic burden: the link between macrocirculation and microcirculation. J Clin Hypertens (Greenwich). 2014;16:186-191. [Crossref]

11. Gur M, Yilmaz R, Demirbag R, Yildiz A, Ozdogru I, Bas MM, et al. Relationship between myocardial performance index and aortic distensibility in patients with essential hypertension. Int J Clin Pract. 2008;62:138-142. [Crossref]

12. Ulucay A, Tatli E. Myocardial performance index. Anadolu Kardiyol Derg. 2008;8:143-148. [Crossref]

13. Lang RM, Badano LP, Mor-Avi V, Afilalo J, Armstrong A, Ernande L, et al. Recommendations for cardiac chamber quantification by echocardiography in adults: an update from the American Society of Echocardiography and the European Association of Cardiovascular Imaging. Eur Heart J Cardiovasc Imaging. 2015;16:233-270. [Crossref]

14. Tei C, Ling LH, Hodge DO, Bailey KR, Oh JK, Rodeheffer RJ, et al. New index of combined systolic and diastolic myocardial performance: a simple and reproducible measure of cardiac function--a study in normals and dilated cardiomyopathy. J Cardiol. 1995;26:357-366. [Crossref]

15. Akyuz AR, Turan T, Gurbak I, Korkmaz L, Agac MT, Celik S. The relationship between presystolic wave and subclinical left ventricular dysfunction in asymptomatic hypertensive patients. Blood Press Monit. 2016;21:277281. [Crossref]

16. Gurbak I, Yildiz I, Panc C. Relation between aortic knob width and subclinical left ventricular dysfunction in hypertensive patients. Clin Exp Hypertens. 2018;40:589-594. [Crossref]

17. Armstrong WF, Ryan T. Feigenbaum's echocardiography. 7th ed. Philadelphia:Wolters Kluwer/Lippincott Williams \& Wilkins Health; 2010. [Crossref]

18. Redon J, Campos C, Narciso ML, Rodicio JL, Pascual JM, Ruilope LM. 
Prognostic value of ambulatory blood pressure monitoring in refractory hypertension: a prospective study. Hypertension. 1998;31:712-718. [Crossref]

19. Cardoso CRL, Salles GF. Refractory hypertension and risks of adverse cardiovascular events and mortality in patients with resistant hypertension: a prospective cohort study. J Am Heart Assoc. 2020;9:e017634. doi: 10.1161/JAHA.120.017634 [Crossref]

20. Gaudieri V, Acampa W, Rozza F, Fillaus JA, Greco BA, Forman JP, et al. Coronary vascular function in patients with resistant hypertension and normal myocardial perfusion: a propensity score analysis. Eur Heart J Cardiovasc Imaging. 2019;20:949-958. [Crossref]

21. Braam B, Taler SJ, Rahman M, Fillaus JA, Greco BA, Forman JP, et al. Recognition and Management of Resistant Hypertension. Clin J Am Soc Nephrol 2017;12:524-535. [Crossref]

22. Viazzi F, Piscitelli P, Ceriello A, Fioretto P, Giorda C, Guida P, et al; AMDAnnals Study Group. Resistant hypertension, time-updated blood pressure values and renal outcome in type 2 diabetes mellitus. J Am Heart Assoc. 2017;6:e006745. doi: 10.1161/JAHA.117.006745. [Crossref]

23. Tei C, Nishimura RA, Seward JB, Tajik AJ. Noninvasive Doppler-derived myocardial performance index: correlation with simultaneous measurements of cardiac catheterization measurements. J Am Soc Echocardiogr. 1997;10:169-178. [Crossref]

24. Tei C, Dujardin KS, Hodge DO, Kyle RA, Tajik AJ, Seward JB. Doppler index combining systolic and diastolic myocardial performance: clinical value in cardiac amyloidosis. J Am Coll Cardiol. 1996;28:658-664. [Crossref]

25. Harjai KJ, Scott L, Vivekananthan K, Nunez E, Edupuganti R. The Tei index: a new prognostic index for patients with symptomatic heart failure. J Am Soc Echocardiogr. 2002;15:864-868. [Crossref]

26. Galiuto L. Value of the myocardial performance index in myocardial infarction. Heart. 2005;91:565-567. [Crossref]

27. LaCorte JC, Cabreriza SE, Rabkin DG, Printz BF, Coku L, Weinberg A, et al. Correlation of the Tei index with invasive measurements of ventricular function in a porcine model. J Am Soc Echocardiogr. 2003;16:442-447. [Crossref]

28. Di Nicolo P, Granata A. Renal Resistive Index: not only kidney. Clin Exp Nephrol. 2017;21:359-366. [Crossref]

29. Raff U, Schmidt BM, Schwab J, Schwarz TK, Achenbach S, Bär I, et al. Renal resistive index in addition to low-grade albuminuria complements screening for target organ damage in therapy-resistant hypertension. J Hypertens. 2010;28:608-614. [Crossref]

30. Tedesco MA, Natale F, Mocerino R, Tassinario G, Calabro R. Renal resistive index and cardiovascular organ damage in a large population of hypertensive patients.J Hum Hypertens. 2007;21:291-296. [Crossref]

31. Quisi A, Harbalioglu H, Ozel MA, Alici G, Genc O, Kurt IH. The association between the renal resistive index and the myocardial performance index in the general population. Echocardiography. 2020;37:1399-1405. [Crossref]

32. Kintis K, Tsioufis C, Kasiakogias A, Dimitriadis K, Konstantinidis D, Andrikou E, et al. Noninvasive assessment of haemodynamics in resistant hypertension: the role of the renal resistive index.J Hypertens. 2017;35:578-584. [Crossref] 